\title{
BOTH MATERNAL AND NEWBORN IgMs INHIBIT INFLUENZA VIRUS-INDUCED HEMAGGLUTINATION IN VITRO
}

\author{
A. P. POGRIBNA ${ }^{1 凶}$, M. Y. GROM ${ }^{2}$, I. V. SOKOL ${ }^{3}$, \\ V. BERESTOVIY ${ }^{3}$ D. O. GOVSIEIEV ${ }^{4}$ \\ ${ }^{1}$ Institute of Molecular Biology and Genetics, National Academy \\ of Sciences of Ukraine, Kyiv; \\ ${ }^{2}$ Research Institute "Zhyttya”, Kyiv, Ukraine; \\ ${ }^{3}$ Bogomolets National Medical University, Kyiv, Ukraine; \\ ${ }^{4}$ Kyiv City Maternity Hospital No 5, Ukraine; \\ 凶e-mail:pogr@ukr.net
}

Received: 16 October 2019; Accepted: 15 May 2020

Most serum immunoglobulins M (IgMs) are "natural IgMs", which are produced apparently spontaneously without exogenous antigenic or microbial stimuli. The IgMs are the first immunoglobulins expressed in the human fetus, and the maternal IgM do not cross the placenta in the normal conditions. We currently lack a clear understanding of the molecular basis for immunological differences or identities of IgM repertoires between adults and neonates, so we have tried to apply a simple and illustrative method to compare the properties of such IgM antibodies. This study was undertaken to compare the abilities of pairs of maternal and newborn highly-purified total serum IgM antibodies to block influenza virus agglutinins. We collected ten pairs of serum samples from cord blood of apparently healthy newborns and venous blood of their mothers. The highly purified total IgM antibodies were obtained by sequential salt fractionation and affinity chromatography. The effect of IgM antibodies on virus hemagglutinin interaction with erythrocytes was evaluated by hemagglutination reaction using influenza virus vaccine. According to the titer of influenza hemagglutinins, the IgM antibodies of newborns decreased hemagglutination of erythrocytes two to four times more efficiently compared to IgM antibodies of their mothers (8 out of 10 cases). Our results demonstrate that serum IgMs of newborns are able to interfere with influenza virus agglutinins even more efficiently than those of adults. These data may be useful for better understanding of immune system development in newborns.

Ke y wo rd s: immunoglobulin M (IgM), cord blood serum, mother venous serum, hemagglutination inhibition assay.

$\mathrm{N}$ ewborns have an immune system that is anatomically intact, antigenically naïve and functionally compromised. Their B cells have a reduced capacity to produce antibodies, their $\mathrm{T}$ cells are functionally weak and their phagocytic cells exert poor mobility and a diminished marrow reserve. All of these weakened responses make infection a significant hazard [1]. Most newborns survive their entry into the external world thanks to innate immunity, passively acquired maternal antibodies, a clean environment and sterile feedings [2].

IgM is the first immunoglobulin expressed in the human fetus (at around 20 weeks of age) [3] and phylogenetically the earliest antibody (Ab) to develop [4]. Maternal IgM, IgA, and IgE antibodies do not cross the placenta, therefore, their concentrations reflect the fetal immune status [5].

IgM acts as first line of defense of an organism and is responsible for recognizing and eliminating infectious particles and transformed cells [6]. Two types of IgMs exist: natural, which are present in an organism without prior antigenic contact; and adaptive, which develop after antigenic challenge [7]. Natural Abs, predominantly IgM and to a lesser extent $\operatorname{IgA}$ and $\operatorname{IgG}[8-10]$, are polyreactive and possess low affinity [11]. Natural IgMs circulate in healthy

(C) 2020 Pogribna A. P. et al. This is an open-access article distributed under the terms of the Creative Commons Attribution License, which permits unrestricted use, distribution, and reproduction in any medium, provided the original author and source are credited. 
individuals in the absence of exogenous antigenic stimulation or antigen (Ag)-driven selection [12, 13]. Natural IgM levels in serum of newborns and in animals that are grown under sterile conditions with an Ag-free diet do not differ from normal ones [7, 14].

IgM in normal serum is often found to bind to specific antigens, even in the absence of prior immunization [15]. This phenomenon is probably due to the high avidity of IgM that allows it to bind detectably even to weakly cross-reacting naturally occurring antigens. Such innate immune response is essential for the generation of a more effective adaptive immune response [15].

The hemagglutination inhibition assay is the most commonly used methodology to determine antibodies to the viral surface protein hemagglutinin (HA) that can prevent agglutination of erythrocytes [16]. The presence of HA inhibiting antibodies, which block the viral attachment to host cells [17], correlates with actual protection from influenza infection [18]. In this study, we aim to compare the abilities of maternal and newborn IgM antibodies to block influenza virus agglutinins from trivalent vaccine GC FLU. The data obtained are helpful in understanding the role of immunoglobulins $\mathrm{M}$ of newborns in neutralizing influenza virus and some aspects of innate immunity of newborns.

\section{Materials and Methods}

Sample collection. Information on gestational age, health of mother and child was obtained by an interview with the curator and clinical data from the hospital.

Sera. 10 maternal-cord serum pairs were collected from apparently normal mothers and from the umbilical cord blood of their infants at the time of delivery at Maternity Hospital 5, Kyiv, Ukraine. Written consent was obtained from all donors and all study procedures were confirmed by the ethical committee of Research Institute "Zhyttya" (Protocol No 2). Umbilical cord blood was collected immediately after birth. Maternal blood was obtained by venipuncture on the day of delivery. Freshly harvested blood was allowed to clot by incubation for $30 \mathrm{~min}$ at $37{ }^{\circ} \mathrm{C}$, then stored for $12 \mathrm{~h}$ at $4{ }^{\circ} \mathrm{C}$, and serum was obtained after centrifugation at $1,500 \mathrm{~g}$ for $30 \mathrm{~min}$ at $4{ }^{\circ} \mathrm{C}$.

All sera were stored in 50\% ammonium sulfate solution at $4{ }^{\circ} \mathrm{C}$ and were not heated before use.

The study was conducted after the approval of the institutional ethical board review and the signed informed consent of each participant.
IgM purification. To obtain total IgM from maternal-cord serum pairs, each serum was treated with saturated ammonium sulfate at $4^{\circ} \mathrm{C}$. After centrifugation at 2,500 $\mathrm{g}$ for $1 \mathrm{~h}$, the precipitate was solubilized in phosphate-buffered saline (PBS) and again treated with ammonium sulfate at $4{ }^{\circ} \mathrm{C}$ overnight (degree of saturation with ammonium sulfate was 35\%). After centrifugation at 2,500 $\mathrm{g}$ for $1 \mathrm{~h}$ at $4{ }^{\circ} \mathrm{C}$, the precipitate was solubilized in PBS and dialyzed overnight. The dialysate was filtered through a $0.45 \mu \mathrm{m}$ filter and then passed through a G-agarose column (ABT, Spain) for maximum depletion of IgG from the samples. Then total serum IgM was purified and concentrated using column chromatography with anti-IgM-resin (Thermo Scientific, Holland). Purified IgM preparations then were filtered through a $0.2 \mu \mathrm{m}$ filter in sterile conditions and stored in $0.1 \mathrm{M}$ glycine buffer, $\mathrm{pH} 7.4$ in aliquots at $4{ }^{\circ} \mathrm{C}$.

Sodium dodecyl sulfate polyacrylamide gel electrophoresis (SDS-PAGE) and Western blotting. All total IgM samples purified from maternal-cord serum pairs were analyzed by SDS-PAGE in $7-22 \%$ gradient of polyacrylamide gel under reducing conditions, as described by Laemmli [19].

Equal amounts of total IgM samples were subjected to $7-22 \%$ SDS-PAGE. Next, the proteins were transferred to $0.45 \mu \mathrm{m}$ nitrocellulose membranes (Amersham Biosciences, GE Healthcare, Germany) using a trans-blot cell (Bio-Rad, US). Then membranes were incubated with anti-human IgM (muchain specific)-peroxidase antibodies (Sigma, Germany) and visualized using ECL reagent (Sigma, England).

Immunoglobulin quantification. Protein concentration (IgM - heavy chain) was determined by sodium dodecyl sulfate-polyacrylamide gel electrophoresis analysis. Coomassie brilliant blue R-250 (Bio-Rad, Hercules, CA) was used to stain the gel, and the molecular weight marker (ApplyChem, Germany) and bovine serum albumin sample with certain concentrations were used for standartization.

Quantification of total IgM purified samples was conducted by using the Image Studio Lite Software 5.2 (LI-COR Biosciences, US). The heavy chain of IgM samples was used for definition of protein concentration in the samples.

Vaccine. GC Flu pre-filled syringe containing a trivalent split-virion influenza vaccine developed by Green Cross Corporation was used. It is an inactivated influenza vaccine derived from fertilized eggs. A $0.5 \mathrm{ml}$ dose of the vaccine contained $15 \mu \mathrm{g}$ 
of each of the three purified hemagglutinin antigens (45 $\mu$ g total): A/Michigan/45/2015 (H1N1), A/ Singapore/INFIMH-16-0019/2016 (H3N2), and B/ Colorado/06/2017. Virus stocks were quantified by a hemagglutination assay to obtain hemagglutination units (HAU).

Isolating and washing erythrocytes. Human blood was obtained by venipuncture using a syringe containing sodium citrate as anticoagulant. Fresh human blood was obtained from healthy donors with the first blood group and Rh positive (Maternity Hospital 5, Kyiv, Ukraine). All subsequent steps after collecting fresh human blood with sodium citrate were performed at $4{ }^{\circ} \mathrm{C}$. After the first centrifugation (1,500 g for $10 \mathrm{~min})$, plasma, and buffy coat were removed. The red blood cells were washed three times with PBS, pH 7.4 (centrifugation at 1,000 g).

Hemagglutination inhibition assay. To evaluate the ability of the total IgM from mother/child pairs to inhibit agglutination of erythrocytes by hemagglutinin antigens of GC Flu vaccines we conducted the hemagglutination assay. The assays were performed in a round-bottomed 96-well plate using 1\% human red blood cells (RBCs) in PBS. Fifty microliters of PBS buffer ( $\mathrm{pH}$ 7.4) were added to each well. The influenza vaccine GC Flu was incubated with IgM samples $(0.06 \mathrm{mg} / \mathrm{ml})$ at $36.7^{\circ} \mathrm{C}$ for $40 \mathrm{~min}$. In the first well row $50 \mu 1$ of control or test sample were added. Each well sample was mixed and $50 \mu 1$ were transferred to the next well on its right. Mixing was repeated and $50 \mu \mathrm{l}$ were transferred down the length of the plate. The $50 \mu \mathrm{l}$ from the last well were discarded. To each well, $50 \mu 1$ of $1 \%$ RBCs working solution were added and mixed gently. The reaction mixture was incubated at room temperature for $60 \mathrm{~min}$ to allow agglutination followed by photography to document the results. Neutralizing antibody titers were defined as the reciprocal of the highest dilution of IgMs that yielded at least 50\% neutralization; reported titers are geometric mean titers (GMTs) from at least 2 replicates.

As influenza positive control the virus vaccine incubated without IgM samples at $36.7^{\circ} \mathrm{C}$ for $40 \mathrm{~min}$ was used. Negative control of IgM samples, Glycine/ PBS buffer alone, was prepared under similar conditions, but without influenza vaccine. The IgMs were dissolved and stored in $0.1 \mathrm{M}$ glycine- $\mathrm{HCl}, \mathrm{pH}$ 7.4. The negative results appeared as dots in the center of round-bottomed plates. The positive results formed a uniform reddish color across the well. The virus vaccine HA titer was determined as the number of the highest dilution factor that produced a positive reading.

\section{Results and Discussion}

Study subjects. To collect the blood sera from the pairs mother/ newborn child, 20 subjects were recruited between November 11, 2018 and May 14 2019. All participants met the screening criteria: natural childbirth, healthy mother, delivery at the terms from 38 to 41 weeks. Basic demographic variables of the subjects, including age of mothers (from 24 to 36 years old), newborn's height (from $50 \mathrm{~cm}$ to $55 \mathrm{~cm}$ ) and body weight (from $3300 \mathrm{~g}$ to 3910 g), medical history, and medication history, were similar between the pairs. It was important to collect from 15 to $30 \mathrm{ml}$ of serum from individual cord blood sample to get required amount of total IgM preparation for further investigations (from 2 to $5 \mathrm{mg}$ total IgM from cord blood sample).

Characterization and quantification of highlypurified total IgM samples from maternal-cord serum pairs. The procedure for obtaining total IgM preparations from sera was carried out under the same conditions for all mother/child pairs.

The IgM samples were affinity purified and maximal IgG deprivation was conducted. During each purification process, a single peak was obtained from the affinity IgM-resin column during the elution with $0.1 \mathrm{M}$ glycine $\mathrm{HCl}$ buffer, $\mathrm{pH}$ 3.06. In SDSPAGE under reducing condition, purified IgM was dissociated into two major bands of 70 and $25 \mathrm{kDa}$. These could be identified as the $\mathrm{H}$ and $\mathrm{L}$ chains of Ig, respectively (Fig. 1). The IgM samples derived from cord blood serum have additional protein bands (approximately $5-10 \%$ out of total protein in the sample) compared with IgM from mother's sera.

All IgM samples from mother-cord pairs obtained by chromatographic procedures were investigated by Western-blot analysis using monospecific anti-immunoglobulin antibodies conjugated with horseradish peroxidase. Such approach was necessary to determine the major band as the heavy chain of IgM in the samples (Fig. 1). The heavy chain of IgM was used as a standard for definition of equal protein sample concentration in the following hemagglutination inhibition assay.

Interaction of the influenza virus vaccine GC Flu with erythrocytes and inhibition of this interaction by the total IgM from maternal-cord serum pairs. The agglutination assays have commonly been exploited to indirectly quantify the titer of the influenza virus, utilizing the specific interaction of 


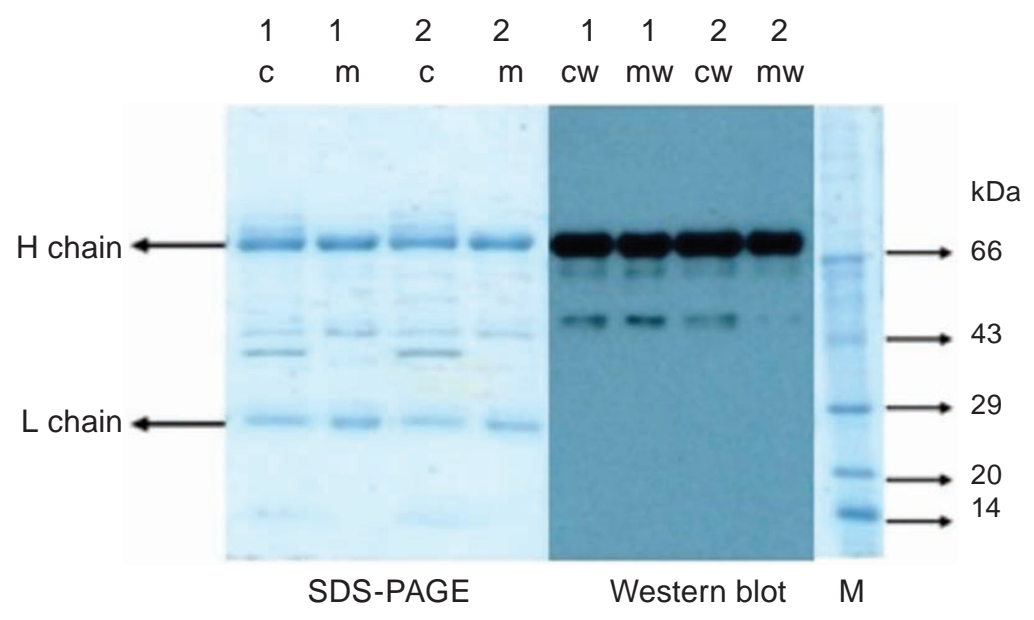

Fig. 1. SDS-PAGE (7-22\%) of human total IgM under reducing conditions. Total IgM from newborn cord blood serum $(1 c, 2 c)$ and their mothers venous blood serum $(1 \mathrm{~m}, 2 \mathrm{~m})$ were separated by SDS-PAGE and detected on Westen Blot using anti-Human IgM (mu-chain specific)-Peroxidase antibodies (Sigma). The heavy chain were detected in all samples of total IgM both from cord blood (1cw, 2cw) and from mothers venous blood serum (1mw, 2mw)

the HA of the influenza virus with glycans expressed on the RBC surface [20]. Fig. 2 represents hemagglutination reaction displayed in a round-bottomed microwell plate after the addition of either IgM or glycine buffer as negative control. Hemagglutination was not observed in the wells containing the IgM or glycine buffer alone. The RBCs agglutinated by the influenza hemagglutinins looked as a diffuse reddish solution. Based on this analysis, the HA titers were calculated as the reciprocal of the minimum dilution forming the red precipitate, indicating one HA unit. The RBCs agglutination by the vaccine hemagglutinins preincubated with 30 or $60 \mu \mathrm{g} / \mathrm{ml}$ of total IgMs was decreased compared to the influenza vaccine control, whereas preincubation with the $15 \mu \mathrm{g} / \mathrm{ml}$ total IgMs from cord blood or with proteins from cord sera without IgMs (precipitated by IgM-resin from cord serum without IgM antibodies) had no effect.

Thus, the optimal concentration of IgM for inhibition of RBC agglutination was defined to be $30 \mu \mathrm{g} / \mathrm{ml}$; it decreased the HA titer of influenza vaccine two to six times (Fig. 3).

The IgM preparations obtained from the cord blood of newborns inhibited erythrocyte agglutination stronger than IgM preparations of their mothers (eight out of ten cases, Fig. 4).

IgM and other immunoglobulin isotypes are produced even before overt exposure to antigen, constituting the so-called natural antibodies [21]. Thus, immunoglobulins are found in human cord blood and in mice that have been kept in germfree con- ditions with minimal exposure to external antigens [22-24]. Therefore, in a normal, non-infected neonate the IgM Abs are predominately not stimulated by foreign Ags (excepting the possibility of Abs developed against maternally transferred Ags) [25].

Among the naturally occurring antibodies, IgM is the most abundant isotype [26]. IgM class Abs do not cross the placenta in significant amounts during normal pregnancy [27], presumably due to their large pentameric structure and the lack of specific transporter mechanism as for $\operatorname{IgG}$ [28]. Therefore, the IgM Abs circulating in the umbilical cord and neonate are predominantly the product of neonatal lymphocytes [29-31].

For a long time it was believed that natural antibodies recognize self-antigens only. However, it has now been demonstrated that natural IgM binds different pathogens and plays a role in defense against infection $[32,33]$. The role of IgM can also be studied in mutant mice that cannot produce the AID protein, which is required both for class switch recombination and somatic hypermutation. Using this model, it was found that unmutated IgM suffices for protection against influenza virus [34]. Overall, natural and/or immune IgM provide protection against many viruses (influenza, West Nile virus, lymphocytic choriomeningitis, vesicular stomatitis, mouse hepatitis, HIV), bacteria (Franciscella tularensis, Ehrlichia muris, Nocardia brasiliensis, Borrelia hermsii, S. pneumoniae, and $P$. aeruginosa), parasites (Toxoplasma gondii, Plasmodium chabau- 


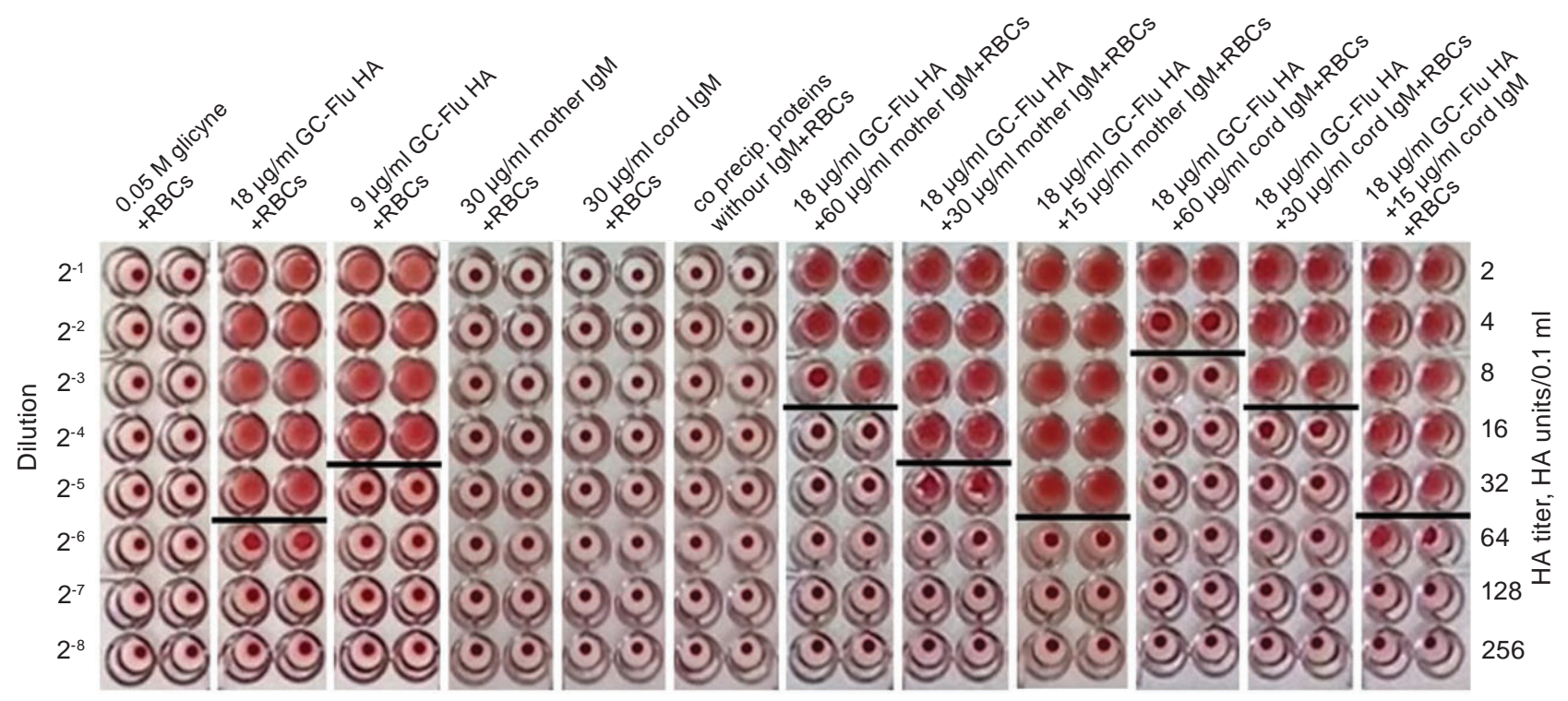

Fig. 2. The IgM inhibition of the human RBCs 0 (1) agglutination mediated by the influenza vaccine GC-Flu $H A$ proteins. Glycine $+R B C s$ : negative control of the used buffer in reaction; mothers $I g M+R B C s$ : negative control of the total IgM obtained from mothers venous blood serum $(30 \mu \mathrm{g} / \mathrm{ml})$; cord IgM + RBCs: negative control of the total IgM obtained from cord blood serum (30 $\mu \mathrm{g} / \mathrm{ml})$; co precip. proteins without IgM+RBCs: negative control of the proteins co precipitated by IgM-resine from cord blood serum without IgMs ( $\approx 20 \mu g$ / ml); GC-Flu HA + RBCs: influenza vaccine HA positive control (with $18 \mu \mathrm{g} / \mathrm{mL}$ and $9 \mu \mathrm{g} / \mathrm{mL}$ ); GC-Flu HA + mother IgM + RBCs: test of the influenza vaccine HA preincubated with total IgMs obtained from mothers venous blood serum at concentrations 60, 30 and $15 \mu \mathrm{g} / \mathrm{ml}$; GC-Flu HA + cord IgM + RBCs: test of the influenza vaccine HA preincubated with total IgMs obtained from cord blood serum at concentrations 60, 30 and $15 \mu \mathrm{g} / \mathrm{ml}$. The HA titer was tested by HA assay. The documented photo is shown as one of eight independent experiments

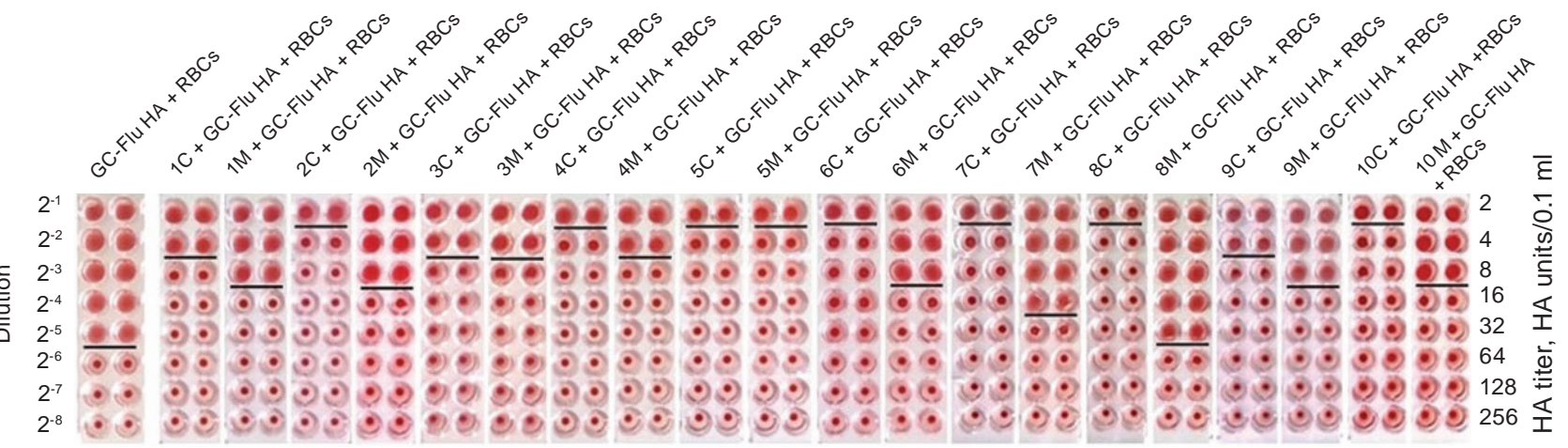

Fig. 3. The IgM inhibition of the human RBCs 0 (1) agglutination mediated by the influenza vaccine GC-Flu $H A$ proteins: comparative analyses between maternal-cord pairs. GC-Flu HA + RBCs: influenza vaccine HA positive control (with $18 \mathrm{mg} / \mathrm{ml}$; GC-Flu HA 1 C (from $1 C$ to $10 C$ ) $+R B C s$ : test of the influenza vaccine HA preincubated with total IgMs obtained from cord blood serum at concentrations $30 \mu \mathrm{g} / \mathrm{ml}$; GC-Flu HA + $1 M$ (from $1 M$ to $10 M)+R B C$ s: test of the influenza vaccine HA preincubated with total IgMs obtained from mothers venous blood serum at concentrations $30 \mu \mathrm{g} / \mathrm{mL}$. The HA titer was tested by HA assay. The documented photo is shown as one of eight independent experiments 


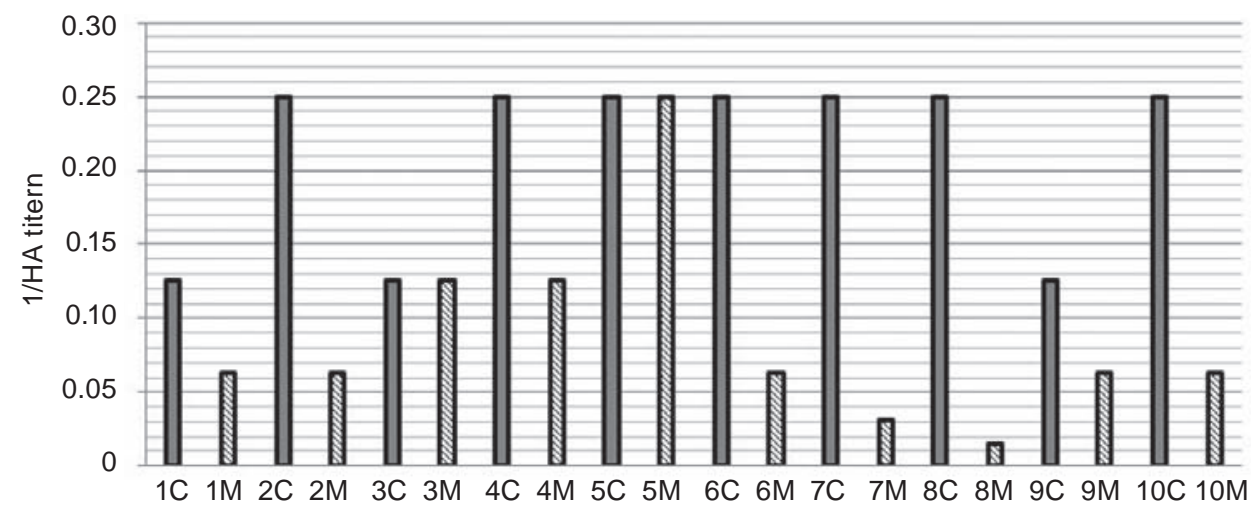

Fig. 4. Demonstration of inhibition effect of RBCs agglutination influenza viruses GC-Flu vaccine proteins by total IgMs obtained from maternal (M) - cord (C) pairs

di/falciparum, Strongyloides stercoralis, Brugia pahangi), and fungi (Cryptococcus neoformans, Candida albicans) $[23,35,36]$.

The aim of our study was to find a simple and illustrative method for comparing the properties of IgM antibodies produced by either the newborn babies or their mothers.

The HAI assay is commonly used to determine the response to influenza virus intervention (eg. following influenza vaccination) due to its ease of performance, good standardization between laboratories and low price [37].

There are several limitations of this study. Firstly, the influenza vaccines are usually produced for one year, according to epidemiology prognosis, and therefore, the hemagglutinin type may vary from year to year. Secondly, the IgM concentration in the cord blood of newborns is smaller compared to that in the blood of adults. In order to obtain comparable amounts of the total IgM, it was necessary to collect at least ten times more cord blood sera than mother's sera. That is why the results presented in this paper are limited to the analysis of only ten maternal-cord serum pairs.

There are many multistep approaches of isolating and purifying human IgM; however, they are often accompanied by significant immunoglobulin loss and not always provide reproducible results [38]. We show here that combining ammonium sulfate precipitation with affinity chromatography was effective in obtaining IgM-rich highly purified samples from maternal-cord serum pairs. We suppose that the isolation of total IgM from human serum by this approach can be useful for the development of immunodiagnostic assays, investigations and comparison of individual immunochemical properties of immunoglobulins from different sources.
In the present study, the total IgMs from maternal-cord serum sample pairs were evaluated for their ability to influence HA-glycan interactions using the agglutination assay. Both the cord blood IgM of newborns and IgM from venous blood of their mothers were found to inhibit the binding of influenza virus vaccine hemagglutinines to the RBCs that causes hemagglutination. Our results demonstrate that the $\mathrm{HI}$ titer was higher in the neonatal than in the corresponding maternal serum (8 out of 10 cases). Direct ELISA and Western blot experiments confirmed that IgM preparations from both newborns and their mothers bound to influenza vaccine and not to erythrocyte antigens (data not shown here).

It has previously been shown that sera from naive mice contain natural IgM that binds to viruses [32]. Natural IgM has been implicated in enhancing the adaptive immune response during influenza virus infection and virus-reactive natural antibody has been demonstrated to bind to various strains of influenza virus [39]. It was shown that passive transfer of natural IgMs significantly reduced the initial level of early morbidity and slightly extended the survival of mice infected with influenza virus [15]. The study by Baumgarth et al. [39] demonstrated that natural IgM produced by B1 cells is important to enhance the response of B2 cells during influenza virus infection. Additionally, Harada et al. showed that non-mutated IgM was able to protect AID deficient mice infected with a lethal dose of influenza virus [34].

The newborns' immune system is still in the state of embryonic development; therefore, the IgMs found in the cord blood are mostly natural antibodies selected by autoantigens. Our results demonstrating that IgMs from the cord blood inhibit hemaggluti- 
nation indicate that self-reactive natural antibodies may mediate virus neutralization. Such antibodies have been shown to be polyreactive [40,41] and may cross-react with pathogen-encoded epitopes [42, 43]. It is known that anti-phosphorylcholine natural antibodies play an important role in protection against streptococcal infections $[44,45]$. Therefore, it is possible that natural IgM antibodies recognize both virus- and host-derived molecules.

Surprisingly, IgM from the newborns inhibited hemagglutination even more efficiently than maternal IgMs. However, their concentration in the blood serum was ten times less than in maternal blood. Probably, this data demonstrate the difference in IgM repertoire of newborns and adults: in newborns it is mostly "natural", selected by autoantigens, while adults have their history of infections, which shape the antibody repertoire. In addition, the majority of B lymphocytes in newborns belong to B1 cells, while in adults the proportion of B1 cells drops to only a few percent. The antibody repertoire of B-1 cells from healthy old individuals differs from that of healthy young individuals in ways that restrict diversity. Beside a cell intrinsic defect in spontaneous immunoglobulin secretion, it was shown a reduction in IgM antibody heterogeneity among B-1 cells from old donors [46].

The data presented here allow suggesting that natural IgM antibodies produced by B1 cells are able to inhibit virus-induced hemagglutination and, therefore, ensure anti-viral protection of newborns. This observation opens the way for further investigation of the role of IgM in innate immunity of newborns and its possible application in medical practice.

Conflict of interest. Authors have completed the Unified Conflicts of Interest form at http://ukrbiochemjournal.org/wp-content/uploads/2018/12/ coi_disclosure.pdf and declare no conflict of interest.

The work was carried out with the support of LLC "Research Institute "Zhyttya”.

Acknowledgments. We would like to thank Dr. Petro Pogribnyy and Nataliia Melnichuk for conceptual contribution in research.

\section{ІМУНОГЛОБУЛІНИ М НОВОНАРОДЖЕНИХ ТА МАТЕРІВ ПРИГНІЧУЮТЬ ІНДУКОВАНУ АГЛЮТИНАЦЮЮ ВІРУСОМ ГРИПУ IN VITRO}

\section{А. П. Погрібна ${ }^{1 凶, ~ М . ~ Ю . ~ Г р о м ², ~ І . ~ В . ~ С о к о л ~}{ }^{3}$, В. О. Берестовий}

${ }^{1}$ Інститут молекулярної біології і генетики НАН України, Київ; ${ }^{2}$ Науково-дослідний інститут «Життя», Київ, Україна;

${ }^{3}$ Національний медичний університет

ім. О. О. Богомольця, Київ, Україна; ${ }^{4}$ Київський міський пологовий будинок №5, Україна; 凶e-mail: pogr@ukr.net

Більшість імуноглобулінів М (IgM) сироватки крові $\epsilon$ «природними $\operatorname{Ig} М »$, які, вірогідно, утворюються спонтанно без впливу екзогенних антигенів або мікробних чинників. Відомо, що $\operatorname{IgM}$ одні з перших імуноглобулінів, які синтезуються в плода людини, однак материнські $\operatorname{IgM}$ не долають плацентарний бар'єр за нормальних умов протікання вагітності. Функціональні відмінності IgM матерів і новонароджених дослідженні мало. Метою роботи було проведення порівняльного аналізу сумарних $\operatorname{IgM}$ матерів та новонароджених блокувати аглютинацію вірусу грипу для визначення можливих функціональних відмінностей між цими антитілами. Високоочищені препарати сумарних IgM було отримано за допомогою методів послідовного сольового фракціонування та афінної хроматографії з десяти пар сироваток мати/новонароджений. Вплив IgM-антитіл на взаємодію еритроцитів за аглютинації вірусними протеїнами визначали за допомогою реакції гемаглютинації 3 використанням вакцини вірусу грипу. Відповідно титру вірусних гемаглютинінів IgM новонароджених знижують гемаглютинацію еритроцитів від двох до чотирьох разів ефективніше порівняно 3 IgM їхніх матерів (8 з 10 випадків). Показано, що сироваткові IgM новонароджених здатні пригнічувати аглютиніни вірусу грипу ефективніше, ніж IgM дорослих. Одержані дані можуть бути корисними для кращого розуміння процесів розвитку імунної системи новонароджених.

К лючов і с лов а: імуноглобуліни $\mathrm{M}$ ( $\operatorname{IgM})$, пуповинна сироватка крові, венозна сироватка крові матері, реакція гемаглютинації. 


\section{References}

1. Walkovich K, Connelly JA. Primary immunodeficiency in the neonate: early diagnosis and management. Semin Fetal Neonatal Med. 2016; 21(1): 35-43.

2. Kwan A, Puck JM. History and current status of newborn screening for severe combined immunodeficiency. Semin Perinatol. 2015; 39(3): 194-205.

3. van Furth R, Schuit HR, Hijmans W. The immunological development of the human fetus. J Exp Med. 1965; 122(6): 1173-1188.

4. Ozdemir SA, Ozer EA, Kose S, Ilhan O, Ozturk C, Sutcuoglu S. Reference values of serum IgG and IgM levels in preterm and term newborns. J Matern Fetal Neonatal Med. 2016; 29(6): 972976.

5. Pineda-Martínez S, Hernández-Islas JL, Escobedo-Torres MP, Paredes-Alonzo IE, López-Candiani C, Correa D, Vela-Amieva M. Immunoglobulin concentrations in plasma and saliva during the neonatal period. Pediatr Neonatol. 2016; 57(3): 213-218.

6. Díaz-Zaragoza M, Hernández-Ávila R, ViedmaRodríguez R, Arenas-Aranda D, OstoaSaloma P. Natural and adaptive IgM antibodies in the recognition of tumor-associated antigens of breast cancer (Review). Oncol Rep. 2015; 34(3): 1106-1114.

7. Klimovich VB. IgM and its receptors: structural and functional aspects. Biochemistry (Mosc). 2011; 76(5): 534-549.

8. Casali P, Schettino EW. Structure and function of natural antibodies. Curr Top Microbiol Immunol. 1996; 210:1 67-179.

9. Coutinho A, Kazatchkine MD, Avrameas S. Natural autoantibodies. Curr Opin Immunol. 1995; 7(6): 812-818.

10. Panda S, Ding JK. Natural antibodies bridge innate and adaptive immunity. J Immunol. 2015; 194(1): 13-20.

11. Lopes-Carvalho T, Kearney JF. Development and selection of marginal zone B cells. Immunol Rev. 2004; 197: 192-205.

12. Madi A, Hecht I, Bransburg-Zabary S, Merbl Y, Pick A, Zucker-Toledano M, Quintana FJ, Tauber AI, Cohen IR, Ben-Jacob E. Organization of the autoantibody repertoire in healthy newborns and adults revealed by system level informatics of antigen microarray data. Proc Natl Acad Sci USA. 2009; 106(34): 14484-14489.
13. Merbl Y, Zucker-Toledano M, Quintana FJ, Cohen IR. Newborn humans manifest autoantibodies to defined self molecules detected by antigen microarray informatics. J Clin Invest. 2007; 117(3): 712-718.

14. Schettino EW, Chai SK, Kasaian MT, Schroeder HW Jr, Casali P. VHDJH gene sequences and antigen reactivity of monoclonal antibodies produced by human B-1 cells: evidence for somatic selection. J Immunol. 1997; 158(5): 2477-2489.

15. Jayasekera JP, Moseman EA, Carroll MC. Natural antibody and complement mediate neutralization of influenza virus in the absence of prior immunity. J Virol. 2007; 81(7): 34873494.

16. Nunes MC, Weinberg A, Cutland CL, Jones S, Wang D, Dighero-Kemp B, Levine MZ, Wairagkar N, Madhi SA. Neutralization and hemagglutination-inhibition antibodies following influenza vaccination of HIV-infected and HIV-uninfected pregnant woman. PLoS One. 2018; 13(12): e0210124.

17. Stegmann T, Bartoldus I, Zumbrunn J. Influenza hemagglutinin-mediated membrane fusion: influence of receptor binding on the lag phase preceding fusion. Biochemistry. 1995; 34(6): 1825-1832.

18. Beyer WEP, Palache AM, Lüchters G, Njauta J, Osterhaus ADME. Seroprotection rate, mean fold increase, seroconversion rate: which parameter adequately expresses seroresponse to influenza vaccination? Virus Res. 2004; 103(12): $125-132$.

19. Laemmli UK. Cleavage of structural proteins during the assembly of the head of bacteriophage T4. Nature. 1970; 227(5259): 680-685.

20. Killian ML. Hemagglutination assay for the avian influenza virus. Methods Mol Biol. 2008; 436: 47-52.

21. Baumgarth N. Innate-like B cells and their rules of engagement. Adv Exp Med Biol. 2013; 785: 57-66.

22. Atif SM, Gibbings SL, Redente EF, Camp FA, Torres RM, Kedl RM, Henson PM, Jakubzick CV. Immune surveillance by natural IgM is required for early neoantigen recognition and initiation of adaptive immunity. Am J Respir Cell Mol Biol. 2018; 59(5): 580-591.

23. Ehrenstein MR, Notley CA. The importance of natural IgM: scavenger, protector and 
regulator. Nat Rev Immunol. 2010; 10(11): 778786.

24. Haury M, Sundblad A, Grandien A, Barreau C, Coutinho A, Nobrega A. The repertoire of serum IgM in normal mice is largely independent of external antigenic contact. Eur J Immunol. 1997; 27(6): 1557-1563.

25. Messmer BT, Sullivan JJ, Chiorazzi N, Rodman TC, Thaler DS. Two human neonatal IgM antibodies encoded by different variableregion genes bind the same linear peptide: evidence for a stereotyped repertoire of epitope recognition. J Immunol. 1999; 162(4): 2184-2192.

26. Heyman B, Shulman MJ. Structure, function, and production of immunoglobulin M (IgM). Encyclopedia Immunobiol. 2016; 2: 1-14.

27. Goudeau A, Yvonnet B, Lesage G, Barin F, Denis F, Coursaget P, Chiron JP, Mar ID. Lack of anti-HBc IgM in neonates with HBsAg carrier mothers argues against transplacental transmission of hepatitis B virus infection. Lancet. 1983; 2(8359): 1103-1104.

28. Malek A, Sager R, Kuhn P, Nicolaides KH, Schneider H. Evolution of maternofetal transport of immunoglobulins during human pregnancy. Am J Reprod Immunol. 1996; 36(5): 248-255.

9. Petit T, Dommergues M, Socié G, Dumez Y, Gluckman E, Brison O. Detection of maternal cells in human fetal blood during the third trimester of pregnancy using allele-specific PCR amplification. Br J Haematol. 1997; 98(3): 767771.

30. Kanaan SB, Gammill HS, Harrington WE, De Rosa SC, Stevenson PA, Forsyth AM, Allen J, Cousin E, van Besien K, Delaney CS, Nelson JL. Maternal microchimerism is prevalent in cord blood in memory $\mathrm{T}$ cells and other cell subsets, and persists post-transplant. Oncoimmunology. 2017; 6(5): e1311436.

31. Scaradavou A, Carrier C, Mollen N, Stevens C, Rubinstein P. Detection of maternal DNA in placental/umbilical cord blood by locus-specific amplification of the noninherited maternal HLA gene. Blood. 1996; 88(4): 1494-1500.

32. Ochsenbein AF, Fehr T, Lutz C, Suter M, Brombacher F, Hengartner H, Zinkernagel RM. Control of early viral and bacterial distribution and disease by natural antibodies. Science. 1999; 286(5447): 2156-2159.

33. Boes M, Prodeus AP, Schmidt T, Carroll MC, Chen J. A Critical role of natural immunoglo- bulin $\mathrm{M}$ in immediate defense against systemic bacterial infection. J Exp Med. 1998; 188(12): 2381-2156.

34. Harada Y, Muramatsu M, Shibata T, Honjo T, Kuroda K. Unmutated immunoglobulin M can protect mice from death by influenza virus infection. J Exp Med. 2003; 197(12): 1779-1785.

35. Racine R, Winslow GM. IgM in microbial infections: taken for granted? Immunol Lett. 2009; 125(2): 79-85.

36. Karlsson F, Tremaroli V, Nielsen J, Bäckhed F. Assessing the human gut microbiota in metabolic diseases. Diabetes. 2013; 62(10): 3341-3349.

37. de Jong JC, Palache AM, Beyer WEP, Rimmelzwaan GF, Boon ACM, Osterhaus ADME. Haemagglutination-inhibiting antibody to influenza virus. Dev Biol (Basel). 2003; 115: 63-73.

38. Nikolayenko IV, Galkin OYu, Grabchenko NI, Spivak MYa. Preparation of highly purified human $\operatorname{IgG}$, IgM, and $\operatorname{Ig}$ A for immunization and immunoanalysis. Ukr Bioorg Acta. 2005; 2: 3-11.

39. Baumgarth N, Herman OC, Jager GC, Brown LE, Herzenberg LA, Chen J. B-1 and B-2 cell-derived immunoglobulin $\mathrm{M}$ antibodies are nonredundant components of the protective response to influenza virus infection. $J$ Exp Med. 2000; 192(2): 271-280.

40. Wang H, Coligan JE, Morse HC 3rd. Emerging functions of natural IgM and its Fc receptor FCMR in immune homeostasis. Front Immunol. 2016; 7: 99.

41. Naparstek Y, André-Schwartz J, Manser T, Wysocki LJ, Breitman L, Stollar BD, Gefter M, Schwartz RS. A single germline $\mathrm{VH}$ gene segment of normal A/J mice encodes autoantibodies characteristic of systemic lupus erythematosus. J Exp Med. 1986; 164(2): 614626.

42. Avrameas S, Alexopoulos H, Moutsopoulos HM. Natural autoantibodies: an undersugn hero of the immune system and autoimmune disorders-A point of view. Front Immunol. 2018; 9: 1320.

43. Haynes BF, Fleming J, St Clair EW , Katinger H, Stiegler G, Kunert R, James Robinson, Scearce RM, Plonk K, Staats HF, Ortel TL, Liao HX, Alam SM. Cardiolipin polyspecific autoreactivity in two broadly neutralizing HIV1 antibodies. Science. 2005; 308(5730): 19061908. 
44. Shaw PX, Goodyear CS, Chang MK, Witztum JL, Silverman GJ. The autoreactivity of anti-phosphorylcholine antibodies for atherosclerosis-associated neo-antigens and apoptotic cells. J Immunol. 2003; 170(12): 61516157.
45. Palma J, Tokarz-Deptuła B, Deptuła J, Deptuła W. Natural antibodies - facts known and unknown. Cent Eur J Immunol. 2018; 43(4): 466-475.

46. Rodriguez-Zhurbenko N, Quach TD, Hopkins TJ, Rothstein TL, Hernandez AM. Human B-1 cells and B-1 cell antibodies change with advancing age. Front Immunol. 2019; 10: 483. 